\title{
BEYOND THE TOLEDO AGREEMENT: THE INTERGENERATIONAL IMPACT OF THE SPANISH PENSION REFORM ${ }^{*}$
}

\author{
Holger Bonin \\ Institute of Public Finance, University of Freiburg \\ D-79098 Freiburg (Germany)
}

Joan Gil

Facultat d'Economia, Universitat de Barcelona

Av. Diagonal 690, 08034 Barcelona (Spain)

\section{Concepció Patxot}

Facultat d'Economia, Universitat de Barcelona

Av. Diagonal 690, 08034 Barcelona (Spain)

September 1999

* We wish to thank J.A. Fernández Cordón for providing us with updated Spanish population projections, and G. Abio, E. Berenguer, G. López-Casasnovas and three anonymous referees for their helpful comments on earlier versions. Joan Gil and Concepció Patxot acknowledge the financial help from CICYT under the project SEC98-0314. 


\begin{abstract}
The paper examines the intergenerational impact of the Spanish public pension system after the 1997 Pension Reform Act. Working within a Generational Accounting framework, we find that maintaining the new legal setting could leave future generations with liabilities as high as 176 percent of base year GDP. As the recent reform measures have been insufficient to achieve the sustainability of the current pension system, we also analyse the impact of alternative reform strategies. Within the current pay-as-you-go setting, a further improvement to tax-benefit linkage in line with the original spirit of the Toledo Agreement is shown to yield and intergenerationally more balanced outcome, than an increase in the retirement age or an expansion of public subsidies financed through indirect taxes. Finally, we examine the generational impact of a move toward a partially funded pension system which might restore the intergenerational balance.
\end{abstract}

Key words: Spanish pension reform, intergenerational redistribution, generational accounting

J.E.L Classification: E62, H55.

\title{
Resumen
}

Este artículo examina el impacto intergeneracional del sistema público de pensiones tras la aplicación de la Ley 24/1997 de Consolidación y Racionalización de la Seguridad Social. Utilizando el método de la Contabilidad Generacional, se obtiene que de mantenerse la nueva configuración del sistema de pensiones podría dejarse a las generaciones futuras una deuda implícita del 176 por ciento del PIB del año base. Dado que las recientes medidas han sido insuficientes para mantener equilibrado el actual programa de pensiones, se analiza el impacto de medidas de reforma alternativas. En el marco del sistema de reparto actual, un reforzamiento de la correspondencia entre pagos y cobros, en el espíritu inicial del Pacto de Toledo, produce el resultado más cercano al equilibrio intergeneracional; frente a un aumento de la edad de retiro, o a una expansión de subsidios públicos financiados a través de impuestos indirectos. Finalmente, se analiza el impacto de un cambio hacia un sistema de pensiones de capitalización parcial, que restaura el equilibrio intergeneracional. 


\section{Introduction.}

The Social Security systems in many of those countries with public pension schemes that work predominantly on a pay-as-you-go (paygo) basis are on the brink of collapse. In the course of the next few decades progressive population ageing will hit most western societies, as a consequence of sharply declining fertility combined with ever-increasing life-expectancy. With a diminished ratio of contributors to pensioners, the financial base of paygosystems is expected to deteriorate. Growing concerns that pension schemes could place severe pressure on future public budgets have fuelled an ongoing debate for Social Security reform in an attempt to prevent substantial future public deficits.

In Spain, population ageing will be particularly severe, due to fertility rates, that have ranked among the world's lowest for almost two decades. Oldage dependency is projected to double in the next fifty years, even if fertility rates recover. ${ }^{1}$ Social Security provision seems poorly prepared for this unfavourable demographic trend: without reforms, the present contributive pension system could run deficits as high as 2 to 3 percent of GDP in the next few decades. ${ }^{2}$ The Spanish government recently enacted a set of reforms to improve the fiscal sustainability of the Social Security system. The 1997 Pension Reform Act was partly inspired by the so-called Toledo Agreement

1 According to the Instituto de Demografía (1994) the old-age dependency ratio (measured as the number of people aged 65 and over per 100 people in the working age 15-64) will increase from 22.5 in 1996 to 33.4 in 2026 reaching 50.5 in 2050. Fernández Cordón (1998) presents similar results.

2 Cf. MTSS (1995), FBBV (1997), Piñera (1996) and Herce and Alonso (1998) 
which, after a series of round-table talks among political parties, social groups and economic experts, was passed by Parliament in April 1995. ${ }^{3}$ One of the main guidelines determining recent legal amendments was the need to strengthen the correspondence between lifetime payroll contributions and individual pension receipts. Herce and Alonso (1998) conclude that the 1997 Pension Reform Act has failed to improve significantly the long-run viability of the Spanish pension system. They estimate the reduction in the annual deficit to be lower than 0.1 percent of GDP in the year 2050. In the light of this, more thorough reform measures appear necessary so as to stabilise Social Security finances. In this paper, we investigate the long-run budgetary impact of various pension reform policies in Spain. Since annual budgets are an ill-defined concept from a neoclassical viewpoint ${ }^{4}$, we employ the intergenerational budgeting concept of generational accounting suggested by Auerbach et al. (1991, 1992). This takes the intertemporal budget constraint of the pension system as a starting point at which to calculate cohort-specific individual lifetime fiscal burdens, which is of obvious relevance in a life-cycle framework. ${ }^{5}$ This method, first applied in Spain by Berenguer et al. (1999) to the entire public sector, not only allows us to compute the implicit liabilities accumulated by pension insurance and the influence of reform measures on its

3 Initially the Toledo Agreement was a mere declaration of purposes. A more specific agreement (Acuerdo de Consolidación y Racionalización del Sistema de Seguridad Social) was signed only in October 1996 by the new government and the two main unions. The 1997 Pension Reform Act (Ley 24/1997, de 15 de Julio, de Consolidación y Racionalización del Sistema de Seguridad Social) culminated the process in seeking a broad consensus on pension reform.

4 Under a neoclassical framework agents are rational and base their consumption and savings decisions upon the impact of fiscal policy on their life-cycle resources.

5 For critical discussions of the generational accounting approach, cf. Raffelhüschen and Risa (1997), Buiter (1997), Havemann (1994) and Diamond (1994). 
sustainability, but it also enables us to analyse the redistributive impact of fiscal reform across generations.

The first concern of this paper is to evaluate the intergenerational impact of the Spanish pension system after the 1997 pension legislation. We conclude that the measures taken are quite insufficient by far to reach intertemporal sustainability. Therefore, we also consider a set of more radical reform proposals. In line with the original spirit of the Toledo Agreement, we compute the intergenerational impact of a higher reduction in average replacement rates than those introduced by the 1997 reform. Further, we investigate measures which are directed at the revenue side of the system, including complementing the payroll scheme with public subsidies financed out of indirect taxes. Finally, as these reform strategies do not eliminate intertemporal redistribution, we analyse the generational impact of a partially funded system that might restore the intertemporal generational balance.

The paper is organised as follows. Section 2 briefly introduces the generational accounting framework. Section 3 discusses the data used and reports generational accounts for the legal status quo. Section 4 analyses the generational impact of various reforms within the current paygo framework. Section 5 proposes a partial funding of future pensions, which ensures intergenerational sustainability. Our main conclusions are presented in section 6.

\section{Generational Accounting for Pension Insurance.}

Conventional generational accounting is based on the intertemporal budget constraint of the overall public sector. As was shown by Boll et al. 
(1994) the method can be modified to address the intergenerational sustainability of public pension insurance. Our computations follow their analysis, but incorporate the most recent methodological refinements suggested by Bonin et al. (1997) and Raffelhüschen (1999).

Assuming that the public pension system does not receive subsidies from other budget authorities, the present value of aggregate payroll contributions made by either presently living or future cohorts and the initial net Social Security wealth must cover the present value of prospective pension expenditure. Let $\mathrm{N}_{t, \mathrm{k}}$ denote the aggregate lifetime net contributions, i.e., Social Security contributions net of pension receipts, paid by all individuals born in year $k$ in present value terms of base year $t$, and $\mathrm{W}_{\mathrm{t}}$ net pension insurance wealth in year $t$. Then, the intertemporal constraint on the future development of contribution revenue and pension expenditure can be written as:

$$
\sum_{\mathrm{k}=t-\mathrm{D}}^{\mathrm{t}} \mathrm{N}_{\mathrm{t}, \mathrm{k}}+\sum_{\mathrm{k}=\mathrm{t}+\mathrm{l}}^{\infty} \mathrm{N}_{\mathrm{t}, \mathrm{k}}=-\mathrm{W}_{\mathrm{t}}
$$

where $D$ denotes the maximum lifespan of individuals. The first sum on the lefthand side of equation (1) aggregates the net contributions of all individuals alive in the base year, whereas the second represents the aggregate net contributions of all generations not yet born.

To analyse the long-term sustainability of pension finances, generational accounting examines if predicted revenue and expenditure levels meet the intertemporal budget constraint described by equation (1). The method derives, for each birth cohort $k$, the base year present value of aggregate remaining lifetime net contributions to the pension system according to:

$$
\mathrm{N}_{\mathrm{t}, \mathrm{k}}=\sum_{\mathrm{s}=\max \{\mathrm{t}, \mathrm{k}, \mathrm{k}}^{\mathrm{k}+\mathrm{D}} \mathrm{T}_{\mathrm{s}, \mathrm{k}}(1+\mathrm{r})^{\mathrm{t}-\mathrm{s}} \quad \mathrm{k}=\mathrm{t}-\mathrm{D}, \ldots, \infty .
$$


In equation (2), $\mathrm{P}_{\mathrm{s}, \mathrm{k}}$ represents the number of individuals born in year $k$ who survive through year $s . \mathrm{T}_{\mathrm{s}, \mathrm{k}}$ stands for the net contribution to Social Security that a representative member of cohort $k$ is predicted to pay in year $s$. The application of a time-invariant discount factor, denoted by $r$, takes all future payments back to the base year. Note that equation (2) only accounts for payments made in or after the base year. Hence, living generations do not enter with their entire life-cycle. ${ }^{6}$

Aggregation of the lifetime net contributions defined by equation (2) provides a direct test on whether a specific pension policy (defined by the predicted matrix of age-specific net contributions $\mathrm{T}_{\mathrm{s}, \mathrm{k}}$ ) is sustainable. If the aggregate for all present and future cohorts is negative and exceeds, in absolute terms, base year Social Security wealth, the pension system accumulates intertemporal liabilities, known in generational accounting as the sustainability gap. If a sustainability gap is observed, the specified time path of contributions and pension transfers is called unsustainable. Future net contributions need to be increased for at least one cohort, in order to meet the intertemporal budget constraint of the pension system.

Calculation of the sustainability gap is sufficient to indicate the long-term viability of a predicted pension policy. In order to evaluate the intergenerational impact of pension policies, generational accounting translates the cohortspecific aggregate net contributions given by equation (2) into per capita fiscal burdens, or generational accounts. Generational accounts are defined to measure, for each cohort, the present value of net contribution payments that a

6 For the sake of argument, our presentation assumes no migration. The modifications necessary for dealing with migration are fully incorporated in the computations [Bonin et al. (1997)]. 
representative member is expected to pay over the remaining life-cycle. The generational accounts for generations alive in the base year, denoted by $\mathrm{GA}_{\mathrm{t}, \mathrm{k}}$, are derived by dividing the aggregate rest-of-life payments under predicted fiscal policy by the initial cohort size:

$$
\mathrm{GA}_{\mathrm{k}}=\frac{\mathrm{N}_{\mathrm{t}, \mathrm{k}}}{\mathrm{P}_{\mathrm{t}, \mathrm{k}}} \quad \mathrm{k}=\mathrm{t}-\mathrm{D}, \ldots, \mathrm{t} .
$$

Due to the forward-looking concept underlying the aggregation of net contributions according to equation (2), the set of generational accounts defined by equation (3) cannot be compared across living cohorts, because they are caught at different stages of their life-cycle. By juxtaposing different policy options, however, the corresponding variations in generational accounts for a given age group will indicate the cohort-specific income effects.

To illustrate the extent to which unsustainable fiscal policy may redistribute consumption possibilities intertemporally from current to future generations, generational accounting applies a special rule in order to derive the lifetime net contributions of cohorts not yet born, who have responsibility for redeeming the intertemporal liabilities of the pension system. Since the eventual policy response to the sustainability gap is impossible to determine, the method relies on a counterfactual experiment. By convention, it is assumed that in order to balance the intertemporal pension budget, generations born after the base year experience a uniform proportional increase in their contribution payments under predicted fiscal policy. This stylised proceeding allows the intertemporal fiscal imbalance to be determined by the difference in lifetime net contribution payments imposed on the base year and future born cohort representatives (both traced over the entire life-cycle). These payments, corrected for income growth, 
would be identical, if predicted pension finances were sustainable. ${ }^{7}$ Unsustainable pension finances, in contrast, are generationally imbalanced, because they impose a higher lifetime net contribution on future generations than on base year newborns.

In our present context, it is worth noting that the reference made by generational accounting to the intertemporal Social Security budget imposes a weaker constraint on the future development of personal tax and transfer levels than the institutional arrangements of a paygo pension system that prohibits annual budget deficits. In a generational accounting framework, by tolerating transitory accumulation of pension liabilities, any predicted contribution and pension transfer policy can be maintained for some time if they are counterbalanced by subsequent adjustments of the pension system redeeming accumulated debt. The clear distinction made between current living and future born cohorts serves to highlight this intertemporal policy conflict.

Typically, generational accounting tests if enacted pension replacement rates and/or observed payroll contribution levels can be maintained in the long term. If base year pension finances work on a paygo scheme, this test represents an extreme policy scenario. It abruptly abandons the valid non-deficit requirement, suggesting that politics would start trying to shift occurring budget imbalances into the future through debt. Adhering, in contrast, to the paygo perspective, the revenue and expenditure parameters of the pension system would be adjusted each year, according to the non-deficit constraint. The continuation of a paygo scheme always achieves intertemporal generational

7 In general, due to predicted changes in the demography or fiscal policy, some variation in the generational accounts of base year and future generations is observed even if the sustainability gap is zero. However, these changes are negligible. 
balance: A policy rule that meets the pension insurance budget annually must do so intertemporally. From a neoclassical viewpoint, however, continuous paygo finance is as extreme a policy scenario as the immediate transition to deficit finance. It deprives government of its ability to redistribute personal consumption possibilities over time or across generations through the accumulation of deficits.

\section{The Collapse of the Present Pension System.}

\subsection{Baseline Data and Parameter Values.}

The construction of generational accounts for Social Security requires the combining of a projection of per capita payroll taxes and pension benefits by age with a long-term demographic forecast. Our population forecast extends the projections provided by Fernández-Cordón $(1996,1998)$, which, reflecting the secular trend in Spain, assume a moderate decline in mortality until the year 2025. In this year, life-expectancy at birth reaches 80.6 years, a gain of 2.8 years compared to our base year 1996. Since the evolution in fertility and migration patterns is difficult to predict, we distinguish two demographic scenarios. In the more optimistic setting, the total fertility rate rises linearly from 1.2 in year 1996 to 1.8 in 2025 . Immigration is determined endogenously by assuming that the absolute size of the workforce is maintained. The age structure of the population at working age changes nonetheless, because the age composition of immigrants differs from that of the initial labour force. The alternative scenario adopts a more pessimistic view. The fertility increase stops at a total fertility rate of 1.6 in year 2025, and annual net immigration is limited to 30,000 migrants. In both scenarios, fertility and mortality parameters are maintained constant after the year 2026 . 
Age- and gender-specific profiles of average individual payroll contributions were derived from the 1996 wave of the Continuous Household Expenditures Survey, a rotary panel run since 1985. The incidence of Social Security contributions is assumed to fall exclusively on labour income earners. ${ }^{8}$ Relative profiles for Social Security receipts by pension type were taken from Social Security administration data. We distinguish between old-age (retirement) pensions which will undergo reform, and other pensions such as disability, orphan and widows pensions, which are kept constant in real terms over the entire projection period.

In line with generational accounting conventions, all original micro profiles were re-evaluated to yield the corresponding macroeconomic aggregate in the base year, taking into account the observed population structure. We assigned 3.67 billion pesetas to old-age pensions and 3.04 billion pesetas to other pensions [IGAE (1997, p. 74)]. As social insurance in Spain adopts a single cash approach, specific contributions to Social Security cannot be isolated. We therefore assumed that payroll revenue was equal to overall pension expenditure in the base year, claiming that pensions were actually paygo-financed. ${ }^{9}$ The resulting cross-sectional cohort profiles of per capita payroll contributions and pension receipts in the base year, which serve as the starting point for the long-term projection of net contributions by age, are summarised in Table 1.

8 This standard incidence assumption is shown empirically valid for Spain by Argimón and González-Páramo (1987) and Escobedo (1991). As the survey collects net income only, we converted net income into gross terms by applying effective income tax rates. Contributions are assumed to be proportional to gross income.

9 This approach might roll over an actual deficit in the pension system -hidden by the single cash approach- to other parts of the social insurance system. If there were a deficit in the base year, the implicit liabilities of the pension system would increase. 
To predict future pension insurance revenue, we submit the initial cohort profile of payroll contributions uniformly to labour productivity growth, held constant at an annual rate of 1.5 percent, which reflects the long term growth trend in Spain. ${ }^{10}$ With respect to pension payment profiles, an alternative rule is applied. Since the Spanish pension system insures against inflation risk only, we assume that the primary insurance amount of consecutive cohorts entering retirement increases at rate $g$ in line with their lifetime income. In retirement, the cohort-specific pension benefits upon death remain constant in real terms. Furthermore, we take into account the final maturing of old-age pensions, which at present are significantly lower for the oldest male generations than they are for cohorts who have retired more recently. For all base year pensioners, the initial cross-sectional average pension levels are maintained upon death. Finally, our projection models the long-term effects of the 1997 Pension Reform Act, which will be discussed in more detail in the following section.

The real discount rate used to take all future contribution and pension payments back to the base year is set at 4 percent. Although the return on Spanish long-term government bonds was markedly higher in the past decade, we expect interest rates to decline to levels similar to those observed in western Europe in the long-term. The recent rapid fall in real interest rates might support this rather optimistic assumption. Finally, since the data do not include base year net assets of the Social Security system, we suppose that pension wealth equals zero, assuming that the provision of public pensions always worked on a purely paygo scheme in the past.

10 MTSS (1995), FBBV (1997), Herce and Alonso (1998) opt for similar values which range from 1.1 to 2.5 percent. 


\subsection{Modelling the Pension Reform Act.}

In July 1997 the Spanish government enacted a Pension Reform Act, based on proposals to reform pension insurance, generally known as the Toledo Agreement. The measures taken aim to rationalise the pension insurance system to consolidate Social Security finances in the face of the demographic challenges ahead. One of the main principles guiding the reform was to strengthen the actuarial fairness of the pension system by improving the correspondence of individuals' lifetime contributions and pension receipts. In investigating the intergenerational sustainability of Spanish pension insurance, we consider the new legal status quo as the baseline. However, we have taken into account only the most significant reform measures of the Pension Reform Act. They are expected to reduce the implicit indebtedness of the pension system, as they lower the average pension received by prospective retirees. To avoid ambiguities, we omit several amendments whose financial effects are difficult to quantify accurately [Herce and Alonso (1998)]. ${ }^{11}$

In particular, our projection of average pension receipts by cohort accounts for two different measures enacted in 1997. First, the reform lowers the average pension of future retirees by reducing the minimum replacement rate guaranteed for labourers with short earning histories. Before the reform, 15 years of contributions ensured 60 percent of the full pension, with each additional year of contributions, up to a maximum of 35 , adding two percentage points. Under the new regime, 15 years of contributions ensure only 50 percent

11 Specifically, our analysis leaves out among others a) the progressive elimination of wage contribution limits for certain professional categories, b) the partial equalisation of contribution payments between the general scheme and categorical schemes, c) the pension increase for some orphans and widows, d) the stricter control envisaged on disability benefits. 
of the full pension, while each year of contributions between the 16th and the 25th adds three, and each year between the 26th and 35th two percentage points of the full pension. Secondly, the 1997 Pension Reform Act changes the pension formula, gradually prolonging the earnings history that enters the calculation of the primary insurance amount from 8 to 15 years between 1997 and 2002. Considering the typical lifetime earnings profile, this measure leads to a decline in assessed past wages, even though wages -except for the final two years- are still adjusted for inflation in the pension formula.

The combination of the two measures is likely to affect the entry level of retirement pensions for future retirees. Following empirical evidence, ${ }^{12}$ we assume that the earnings history of a representative wage income earner lasts 30 years and that he or she retires at the age of 63. In addition, we set past real wage growth at 1.5 percent per annum and suppose that annual inflation equals 2 percent. In this scenario, pensioners experience a gradual decrease in old-age benefits which ranges from 0.74 percent for those retiring in 1997 to 4.96 percent for all those retiring after the year $2002 .{ }^{13}$ It is worth noting that, under the given assumptions, the new treatment of workers with short earning histories does not affect the percentage of the average pensionable wage received by the representative individual at all: with 30 years of contributions he or she can still expect 75.6 percent of the average pensionable wage under

12 Cf. MTAS (1997) and Monasterio et al (1996).

13 Pensions in Spain are bound by an upper and lower limit. Since pensioners who receive a maximum or minimum pension are less affected by reform, we overstate the pension cut referring to a representative individual whose pension benefit falls within these limits. The bias might be quite important considering that, in 1996, 30 percent of agents entering into retirement received a pension complement [MTAS (1999)]. However, an estimate including income heterogeneity would require a more powerful data set. 
the new legislation. ${ }^{14}$ The entire reduction in the average pension level can be attributed to the less generous formula used to compute the primary insurance amount.

\subsection{Baseline Generational Accounts.}

Figure 1 plots the baseline generational accounts for each cohort alive in 1996 and a representative future generation, given the high fertility demographic scenario. The generational accounts for the living exhibit a characteristic life-cycle pattern. The present value of lifetime net contributions to Social Security is positive for a base year newborn. His or her lifetime contributions exceed lifetime pension receipts by 1,371 thousand pesetas in present value terms, suggesting that the internal rate of return of payroll contributions is rather low. During childhood and youth, the generational accounts gradually increase with cohorts' age, because the period of contribution payments and pension receipts is less heavily discounted. Remaining lifetime tax payments reach their maximum with entry into the labour force. The generation aged 20 in the base year faces a net contribution burden of about 2,171 thousand pesetas in present value.

After reaching the peak, the generational accounts fall continuously for cohorts initially in the labour force. Their shorter contribution period and less discounted benefits offset the effects of rising income with working age. Restof-life net contributions become negative for the 35-year-old who, over his remaining life-cycle, receives a net transfer from public pension insurance. The

14 Since the average earnings history is five years short of the necessary career of 35 years, full replacement is first reduced by 10 percent. An additional 8 percent, or 7.2 percentage points, are deducted for each year of early retirement. 
maximum transfer is attained by the cohort who is of legal retirement age (65) in the base year. For all older cohorts, remaining lifetime pension receipts gradually decrease according to their shorter life-expectancy. Although the remaining lifetime net contributions of cohorts at different stages of their lifecycle should not be compared, the cohort pattern of generational accounts reveals a distinctive feature of the Spanish pension system. The fact that the maximum net payment to pension insurance amounts to only about 15 percent of the maximum receipts suggests significant income redistribution across generations in favour of retirees. This is similar to results presented by Gil and López-Casasnovas (1998).

Turning to the question of intergenerational sustainability, we find that the present Social Security system could leave future generations with an overwhelming bill, despite the measures enacted by the 1997 pension reform. Maintaining the current state of pension insurance accumulates liabilities as high as 175.7 percent of base year GDP. If intertemporal pension debt is allocated entirely to generations not yet born, lifetime net contributions to Social Security imposed on a representative member, amounting to 7,143 thousand pesetas, are almost five times higher than the generational account of a base year newborn (1,371 thousand pesetas). This mammoth degree of intergenerational redistribution induced by demographic ageing puts in doubt the long-run viability of the pension system.

Our findings also indicate that the 1997 Pension Reform Act has achieved little to shield Social Security against the demographic challenges that lie ahead. If we withdraw the envisaged pension cut from the baseline, the implicit liabilities accumulated by the pension system, worth 187.6 percent of 1996 GDP, are only insignificantly higher. This result is not surprising, considering 
that the reform imposes only a very moderate burden on the present living. According to the generational accounts, the envisaged pension cut raises the lifetime net contributions of a base year newborn by a mere 6.1 percent. Furthermore, policymakers have left transfers to base year pensioners untouched, as the reform guarantees existing pensions.

Our finding that the current state of Spanish pension insurance is unsustainable holds for a wide range of scenarios. Variations in productivity growth and interest rates within a reasonable range do not alter the basic impression of severe intertemporal generational imbalance. Supposing, for example, annual growth of 2 percent and a discount rate of 3 percent yields a generational imbalance of 7,359 thousand pesetas. Compared with the baseline, this scenario gives greater weight to distant pension payments in an aged society, which increases the intertemporal deficit. At the opposite extreme, employing a growth rate of 1 percent and an interest rate of 5 percent leads to a generational imbalance of only 4,625 thousand pesetas, because this scenario gives more weight to the favourable demographic development over the next decade which temporarily leads to a particularly large labour force. Yet, the intergenerational fiscal imbalance remains sizeable.

Furthermore, the choice of the demographic setting does not seriously change our qualitative findings. Not surprisingly, employing the pessimistic demographic scenario outlined in section 3.1 leads to an even greater intergenerational redistribution. The additional contribution burden of future cohorts amounts to 8,658 thousand pesetas, compared to 5,772 thousand pesetas in the baseline. Of course, assuming an even more optimistic fertility development than in the already optimistic baseline would show an improved sustainability of the pension system. However, in line with other generational 
accounting studies, we find that the overall impact of future fertility on the tax burden of future generations remains insignificant.

\subsection{A Paygo Perspective.}

As explained in section 2, the fiscal imbalance revealed by the generational accounting analysis is the result of a thought experiment that abandons the non-deficit requirement of the existing paygo scheme immediately after the base year. To investigate the opposite extreme, one could maintain the original paygo setting indefinitely, adjusting contribution and/or replacement rates annually. The paygo perspective, eliminating intertemporal generational imbalance, translates the sustainability gap of the Spanish pension system into time paths of payroll contribution and replacement rates. It differs from the generational accounting viewpoint by allocating the burden from population ageing among all present generations and future cohorts. Obviously, any 'real world' development would be found between the two extremes of rigidly maintained paygo practice and a policy that switches to the accumulation of debt rolled over to future generations.

We investigate two polar scenarios, which maintain the paygo system indefinitely. The first is a defined benefit plan. Contribution rates are adjusted annually to ensure a zero deficit, while the original replacement rate of pensions are preserved. The alternative is a defined contribution plan, which takes the pension level as endogenous and fixes base year contribution rates. Figure 2 plots the development of contribution rates and pension levels in both scenarios, indexing the respective base year level as 100. Reflecting the demographic development, endogenous adjustment of contributions or transfers mainly takes place in the three decades after year 2015, before the system converges to a 
stable state. The adjustments needed to maintain paygo finance are sizeable pensions need to be reduced by about 50 percent at the maximum, or contributions need to be raised by 100 percent. In the light of these figures, the viability of the Spanish pension system would once again seem to be in doubt. However, the rather favourable demographic environment over the next two decades might seduce short-sighted politicians in postponing the necessary reforms.

Both paygo scenarios leave cohorts at the beginning of their working life or younger with the highest burdens in present value terms. These cohorts live entirely through the period of highest contribution rates or lowest pension replacement. Other cohorts are affected too, but to a lesser extent. A defined benefit plan does not burden base year pensioners, in contrast to the endogenous pensions scenario, where they share their part of the fiscal burden due to population ageing. As a consequence, the two policies yield significantly different lifetime net contributions. With endogenous pensions, the generational account of a base year newborn amounts to 2,791 thousand pesetas compared to 1,371 thousand pesetas in the generational accounting scenario. Allocating parts of the fiscal burden to present pensioners almost doubles the lifetime contribution rate to pension insurance for a current newborn, to the advantage of future generations who are left with a significantly lower burden $(2,784$ thousand pesetas instead of 7,143 thousand pesetas). Since the defined benefit plan exempts current pensioners, the sacrifice required from the remaining cohorts is necessarily greater. Moreover, the adjustment of contributions hits at an earlier, less discounted stage of the life-cycle. Therefore, the sustainable generational account of a base year newborn, facing a lifetime tax burden of 4,675 thousand pesetas, is almost twice that of a defined contribution plan. 
Adopting a generational accounting approach, it is impossible to choose between these two extreme paygo policies, which are moreover hardly politically feasible. By definition, paygo strategies restore intergenerational sustainability, which is the essential normative criterion of the method. Policy recommendations beyond the pure aggregation of payment streams require a welfare analysis which only a general equilibrium model can provide.

It is probable that efficient policy requires a combination of the two systems. Positive reasons could shift policy choice in the direction of reduced pensions: first, the lower life-cycle contribution rate implied might reduce the labour market distortions of pension insurance. Second, it might be reasonable to punish future pensioner cohorts for their fertility behaviour which is partially responsible for the demographic destabilisation of the system. ${ }^{15}$

\section{Reforming the Paygo System.}

The lesson from the above analysis is obvious. The recent attempt at reform in an effort to prepare Spanish pension insurance for demographic ageing was insufficient to set Social Security finances on a sustainable longterm path. There is a need for further reform. In this section, we investigate the intergenerational impact of alternative policy measures that might become part of the political agenda to restore intergenerational sustainability. All reform experiments are judged against the baseline established by the 1997 Pension Reform Act.

15 Patxot (1994) and Abio and Patxot (1999) argue that cohorts entering retirement in an ageing population have partially opted out of the investment in children. Their higher 


\subsection{Strengthening the Tax-Benefit Linkage.}

One intention of the 1997 Pension Reform Act was to improve the taxbenefit linkage of pension insurance. Politicians have been reluctant, however, in transferring the suggestions of the Toledo Agreement into law. In a first experiment, we investigate the impact of a more rigid attempt to strengthen the tax-benefit linkage by lowering the entry pension level of future pensioners. In line with the strategies analysed by Monasterio et al. (1996) and FBBV (1997), we assume that the more severe measures to reduce pension levels are gradually introduced over a period of 20 years. A faster, fiscally more effective pension cut would have problems in gaining political support, due to sizeable adjustment costs.

Our experiment accounts for three reform proposals. First, we assume that the maximum number of contribution years required to receive a full pension is increased linearly from 35 to 40 within five years from the base year, approaching a standard set by many OECD countries [World Bank (1994)]. At the same time, strict proportionality is introduced with respect to the weight of each year of contributions, rather than giving a higher weight to the first 15 years of payments. We claim that from the year 2001 on, each year of contributions gains the same percentage -2.5 percent of the full pension. Given that earning careers, on average, last 30 years, this policy reduces the pension obtained by a representative contributor by 15 percentage points, compared to the baseline legal setting.

personal lifetime consumption possibilities might offset the lower pension received from a paygo insurance with fixed contribution level. 
Secondly, on computing the primary insurance amount we take into account the full earnings history. From 1997 to 2002, one additional year enters the average pensionable wage formula. From 2003 onward, two additional years are considered, until a maximum of 40 years is reached in year 2015. Finally, we assume that the reform strengthens the incentives to refrain from early retirement. For each year of early retirement, the pension loss is raised from 8 to 9 percent. The combination of the three measures leads to a marked reduction in future pensioners' primary insurance amount. For a representative individual with 30 years of average contributions who retires at age 63, the pension cut amounts to about 30 percent from year 2010 on.

The intergenerational impact of this set of reform measures is summarised in the second column of Table 2, which reports the basic generational account indicators for the pension reforms analysed in this section. A closer correspondence between lifetime contribution payments and pensions received clearly enhances the sustainability of the Social Security system. Implicit liabilities of the pension insurance are reduced by almost 60 percentage points to 116.5 percent of base year GDP. Accordingly, fiscal imbalance between current and future newborns declines to 3,826 thousand pesetas $(5,772$ thousand pesetas in the baseline). Future newborns are relieved at the expense of the present living. Over the entire lifetime of a base year newborn, net pension contributions rise by about 400 thousand pesetas. Still, the reform goes no way to achieving intergenerational balance, mainly due to its smooth introduction which delays its full effect, and the exemption of current pensioner cohorts whose pension entitlements are left untouched. Hence, a policy toward a more actuarial fairness needs to be complemented with other reform measures. 


\subsection{Payroll Contributions versus Indirect Taxes.}

In Spain, indirect taxes, and value-added taxes (VAT) in particular, are well below the EU average at present [Alonso et al. (1997)]. Since the harmonisation of indirect tax rates within the EU is still a major political objective, there seems to be scope for raising VAT. This section investigates the intergenerational impact of an immediate and permanent increase in the average VAT tax rate. The revenue increment serves to reduce payroll contributions to Social Security by the same amount so that the base-year budget of pension insurance remains balanced. The idea of substituting payroll contributions by public subsidies financed out of consumption based taxes is appealing. In general, consumption is spread more evenly over the life-cycle than labour income. Relying on consumption taxation to finance social security gives pensioners a share in financing pensions (reducing the net transfer to the old), which could render pension finances less prone to demographic ageing.

In our experiment, we assume that the current normal VAT rate (16 percent) is raised by three percentage points, which brings it close to the European average of 19.4 percent. Taking the average Spanish VAT rate of 13.25 percent [MEC (1995)] as a starting point, we find that a one percentage point increase in the normal VAT rate collects 289.6 thousand million pesetas of additional revenue, which means that the implicit contribution rate to Social Security can be reduced by 1.22 percentage points. ${ }^{16}$ The additional VAT

16 This reasoning neglects general equilibrium considerations, or even partial equilibrium effects on the labour market. Higher consumption taxes induce positive macroeconomic repercussions, eliminating labour market distortions and raising incentives to save [LopezGarcía (1996)]. Generational accounting omits these dynamic effects, and is limited to first-round income effects. For Spain, the results of Vilches and Salas (1994) and Nadal (1994) suggest that the possible reduction in the payroll contribution rate might be actually 
payments are allocated by age using a consumption profile retrieved from the Continuous Household Expenditures Survey.

As can be seen from the third column of Table 2, the switch to a consumption oriented revenue base to finance public pensions does not enhance the sustainability of pension finances. Intergenerational redistribution is hardly affected at all because the life-cycle effects of the reform cancel out in present value terms. The generational account of a present newborn rises by a mere one thousand pesetas. Only present pensioners who expect slightly reduced rest-oflife net transfers face a significant burden in comparison to the baseline. Their tax payments reduce the intertemporal liabilities of the pension system by about 4 percentage points, to 172 percent of base year GDP. Accordingly, the tax burden of future generations falls by no more than 125 thousand pesetas.

This unexpected result mainly reflects the age-specific profile of average VAT payments in Spain. In contrast to many other countries, indirect tax payments are spread in a similar manner to payroll contributions among age groups. It is beyond the scope of this paper to decide whether this is due to a peculiarity of the Spanish tax system (or consumption behaviour), or due to deficiencies in the microeconomic data. If the former is true, pension policy cannot expect much from a switch in the tax base toward consumption.

\subsection{Increasing Retirement Age.}

The 1997 Pension Reform Act did not establish measures to raise the retirement age, although this seems an obvious means to curb the effects of

higher. Thus, our findings provide only a lower bound of the improvement of sustainability. 
reduced mortality, which has prolonged the average lifespan in retirement. Nevertheless, the retirement age in Spain is likely to increase in the second half of the next decade, since current legislation does not grant early retirement to generations who started paying payroll contributions after year 1967. On evaluating the intertemporal fiscal impact of variations in retirement age, we assume that retirement, on average, will be postponed by two years. It might be thought that this can be achieved by raising the official retirement age, or by removing incentives for early retirement [Gómez-Sala (1993)].

To model the increase in effective retirement age, we assume that the original relative age profile of old-age pension receipts is shifted forward by two years. This process takes place over a period of five years from the base year. Since the incentives on active labour force participation are rather difficult to predict, the relative age profile of payroll contributions remains unchanged in our computations. This neglects the potential revenue effects of a prolonged working life. Furthermore, by not considering the pension increase caused by a longer stay in the labour force, we assume that the current pension system is actuarially fair, at least as far as the final years at the end of the working career are concerned.

An increment in retirement age significantly improves the sustainability of the pension system, which can be seen from the final column of Table 2. It raises the generational accounts of all living cohorts younger than 65 , because of the prolonged working period and reduced benefits in retirement. As a consequence the intertemporal liabilities accumulated by the system fall by about 30 percentage points to 146.5 percent of the 1996 GDP. Therefore, pension finances are intergenerationally more balanced. While present newborns experience net lifetime contributions of 1,590 thousand pesetas, 
future generations are exposed to a 4,813 thousand pesetas higher burden, contributing 6,403 thousand pesetas net.

Although the increase in retirement age itself could not restore intergenerational balance, it helps, applied together with other measures, to readdress the long-term viability of the pension system. Combined with the harder realisation of the Toledo Agreement discussed in section 4.1, it lets implicit pension liabilities decline to around 80 percent of GDP. Hence, there seems to exist a non-negligible potential for reforms within the existing system.

\section{Restoring Sustainability: A Move Toward Partial Funding.}

Section 4 focused on reforms directed at restoring intergenerational balance within the existing paygo framework, none of which were sufficient to ensure intergenerational sustainability of the pension system. As was shown in section 3.4, intergenerational balance could be achieved through fully endogenous taxes and/or transfers. Yet, the associated fiscal burdens which are spread unevenly among cohorts are unlikely to be tolerated by those generations affected.

To reduce the demographic pressure on paygo Social Security, several countries have made steps forward to (partially) funded pension systems. In a funded system, the rapidly increasing demand of old-age pensions in an ageing population is met by the accumulation of a capital stock in good time. The transition to a funded system puts a double fiscal burden on cohorts living during the transition period. In order to accumulate an asset that can be handed over to prospective retirees, they have to forego part of their current income, but at the same time must finance the requirements of the expiring paygo system. 
Nevertheless, the transition to a funded system can be pareto-superior if economic distortions originating from the paygo system are eliminated. Dynamic efficiency gains may suffice to compensate the generations living through the transition [Raffelhüschen (1993)].

In the following, we employ generational accounting to derive a partial funding strategy for Social Security in Spain. We calculate the immediate onceand-for-all proportional variation in contribution and/or pension levels that eliminates intertemporal liabilities of the pension system, thereby assuring intergenerational balance. Since all adjustments take place immediately, the pension insurance runs surpluses in the first few decades, when the ratio of contributors to pensioners is favourable. As soon as the demographic situation worsens, the accumulated assets are employed to partially finance the pension claims of an increased number of retirees. ${ }^{17}$

Reflecting the high implicit liabilities of the pension system in the baseline setting, the immediate and permanent policy changes required to achieve partial funding are severe. To accumulate the required assets, contributions must be raised by 43.2 percent, or 6.2 percent of 1996 GDP. A 30.1 percent immediate cut in all pensions, corresponding to a reduction in pension spending by 2.8 percent of base year GDP, fulfils the same task. As a less extreme alternative, we consider a solution that raises half of the needed funds by contributions, and half by a pension cut. This policy is a linear combination of the extreme scenarios. Payroll contributions are raised by 21.6 percent and pensions cut by 15.5 percent.

17 This is a stylised view on the transition to partial funding. Any immediate adjustment would be difficult to implement. In practice, one would prefer a more gradual transition, 
The generational impact of the alternative funding strategies varies considerably. Compared with a sustained paygo system, partial funding is the preferred strategy of the present young and future generations. The immediate increase of payroll contributions leaves newborns with a lifetime net contribution of 3,333 thousand pesetas, against a burden of 4,675 thousand pesetas under a defined benefit plan. Opting for an immediate pension cut lets current pensioners participate in the accumulation of temporary Social Security wealth. Consequently, the lifetime tax burden for present young and future generations is reduced even more. A representative newborn is left with 2,328 thousand pesetas, which is again less than in the corresponding defined contributions scenario $(2,791$ thousand pesetas $)$.

Despite these results, the generational accounts do not generally support of partial funding. This can be seen from Figure 3 which depicts the agespecific deviations from the baseline accounts for all three funding strategies, and the paygo scenario with endogenous pensions. It reveals that a policy that continually adjusts pension levels instead of raising contributions once-and-forall is preferred by all cohorts younger than 40 , at the expense of older base year cohorts. This result should be treated with some caution of course, because it neglects the macroeconomic repercussions of funding strategies. In particular young and future cohorts would benefit from a higher capitalisation of the economy that is likely to result from the accumulation of a capital stock for Social Security. At this stage, the basic generational accounting approach hits a

and should opt for personalised pension accounts, to put pension wealth out of the reach of greedy politicians. 
limit which can be overcome only with a general equilibrium approach that is beyond the scope of this paper. ${ }^{18}$

Considering political feasibility, the government might want to opt for a funding strategy that spreads the transitional burdens most evenly among all cohorts. In this respect, Figure 3 suggests that a mixed strategy which leaves equal parts of the adjustment costs to contributors and pensioners is more balanced generationally. Less perceptible than the alternatives, this policy may have greater potential in finding support from a majority of voters willing to preserve Social Security insurance, but trying to minimise their share in the resulting fiscal burdens. To determine the combination of contribution raise and pension cut that would obtain the strongest backing from Spanish citizens, a more thorough analysis of political economy would be required, however.

\section{Summary.}

The intergenerational redistributive impact of the Spanish public pension system after the 1997 Pension Reform Act has been the concern of this paper. Using generational accounts we find that even the new legal setting leaves future generations with a lifetime contribution rate that is five times higher than that of current newborns. Stated differently, implicit debt rolled over to future generations amounts to 176 percent of base year GDP. Recent reform attempts at reform effort have done little to improve the long-run sustainability of what remains a generous Social Security system. If a paygo setting is maintained,

18 Taking into account macroeconomic repercussions within a generational accounting context, Raffelhüschen and Risa (1997) demonstrate the ambiguous impact of a funding strategy on individual welfare. 
contribution rates must double within the next fifty years, or replacement rates must be cut by half.

Since either development questions the long-term political feasibility of the system, policymakers must consider more vigorous reform measures. There appears to be scope for reducing the intertemporal fiscal imbalance while maintaining paygo finance. A further improvement to tax-benefit linkage, in line with the original intentions of the Toledo Agreement, which gradually lowers average pensions for prospective retirees by 30 percent, is sufficient to reduce the implicit liabilities of the Social Security system by about 60 percentage points of GDP. Combined with an increase in effective retirement age by two years, a more stringent realisation of the Toledo Agreement cuts pension liabilities even further (to about 80 percent of current GDP).

Nevertheless, reforms within the paygo system are unlikely to be sufficient to restore the intergenerational balance. To achieve sustainable pension finances, a complementary transition to a partially funded system might be advisable. Strategies which generate the required funds through either contribution raises or pension cuts distribute transition costs rather unevenly among the present living. Our findings support a mixed funding which spreads the funding burden more equally between current contributors and retirees. The latter strategy might provide a useful starting point for the necessary re-thinking of Social Security reform in Spain. 
Table 1: Average Payroll Contributions and Pension Receipts, 1996 cross section

\begin{tabular}{rrrrr}
\hline \multirow{2}{*}{ Age } & \multicolumn{2}{c}{ Payroll Contributions $^{\mathrm{a}}$} & \multicolumn{2}{c}{ Pension Receipts $^{\mathrm{a}}$} \\
& \multicolumn{1}{c}{ Males } & Females & \multicolumn{1}{c}{ Males } & \multicolumn{1}{c}{ Females } \\
\hline 16 & 5,300 & 3,900 & 0 & 0 \\
20 & 47,100 & 40,400 & 0 & 0,100 \\
25 & 167,500 & 125,200 & 0,100 & 0,300 \\
30 & 308,500 & 229,800 & 0,400 & 1,100 \\
35 & 433,600 & 307,000 & 1,500 & 3,000 \\
40 & 505,500 & 321,000 & 3,800 & 7,400 \\
45 & 546,300 & 322,200 & 8,400 & 18,400 \\
50 & 547,400 & 260,500 & 18,700 & 47,500 \\
55 & 425,400 & 189,800 & 48,300 & 175,600 \\
60 & 231,200 & 130,200 & 328,700 & 447,800 \\
65 & 61,700 & 36,700 & 925,600 & 750,900 \\
70 & 2,700 & 4,100 & $1,194,400$ & 914,200 \\
75 & 6,200 & 3,400 & $1,117,600$ & 948,700 \\
80 & 11,500 & 1,200 & 968,600 & 926,300 \\
85 & 0 & 0 & 873,900 & 910,300 \\
90 & 0 & 0 & 855,900 & \\
\hline
\end{tabular}

${ }^{a}$ All payments re-evaluated to aggregate pension insurance revenue and expenditure (6.71 billion pesetas).

Sources: ECPF (1996), INSS (1995, p. 281), Authors' calculations

Table 2: The Intergenerational Impact of Pension Reforms

\begin{tabular}{lcccc}
\hline & \multicolumn{3}{c}{ Scenario } & \\
& $\begin{array}{c}\text { 1997 Pension } \\
\text { Reform Act } \\
\text { (Baseline) }\end{array}$ & $\begin{array}{c}\text { Improvement of } \\
\text { Tax-Benefit } \\
\text { Linkage }\end{array}$ & $\begin{array}{c}\text { Move to Indirect } \\
\text { Tax Base }\end{array}$ & $\begin{array}{c}\text { Raise in } \\
\text { Retirement Age }\end{array}$ \\
\hline $\begin{array}{l}\text { Sustainability gap } \\
\text { (percent of 1996 GDP) }\end{array}$ & 175.7 & 116.5 & 172.0 & 146.5 \\
$\begin{array}{l}\text { Generational Accounts } \\
\text { (1000 Pesetas) }\end{array}$ & 1,371 & 1,774 & 1,373 & 1,590 \\
Base Year Newborns & 7,143 & 5,600 & 7,018 & 6,403 \\
Future Newborns & 5,772 & 3,826 & 5,646 & 4,813 \\
Generational Imbalance & & & &
\end{tabular}


Figure 1: 1996 Social Security Accounts of Present and Future Generations (Baseline, $g=0.015, r=0.04$ )

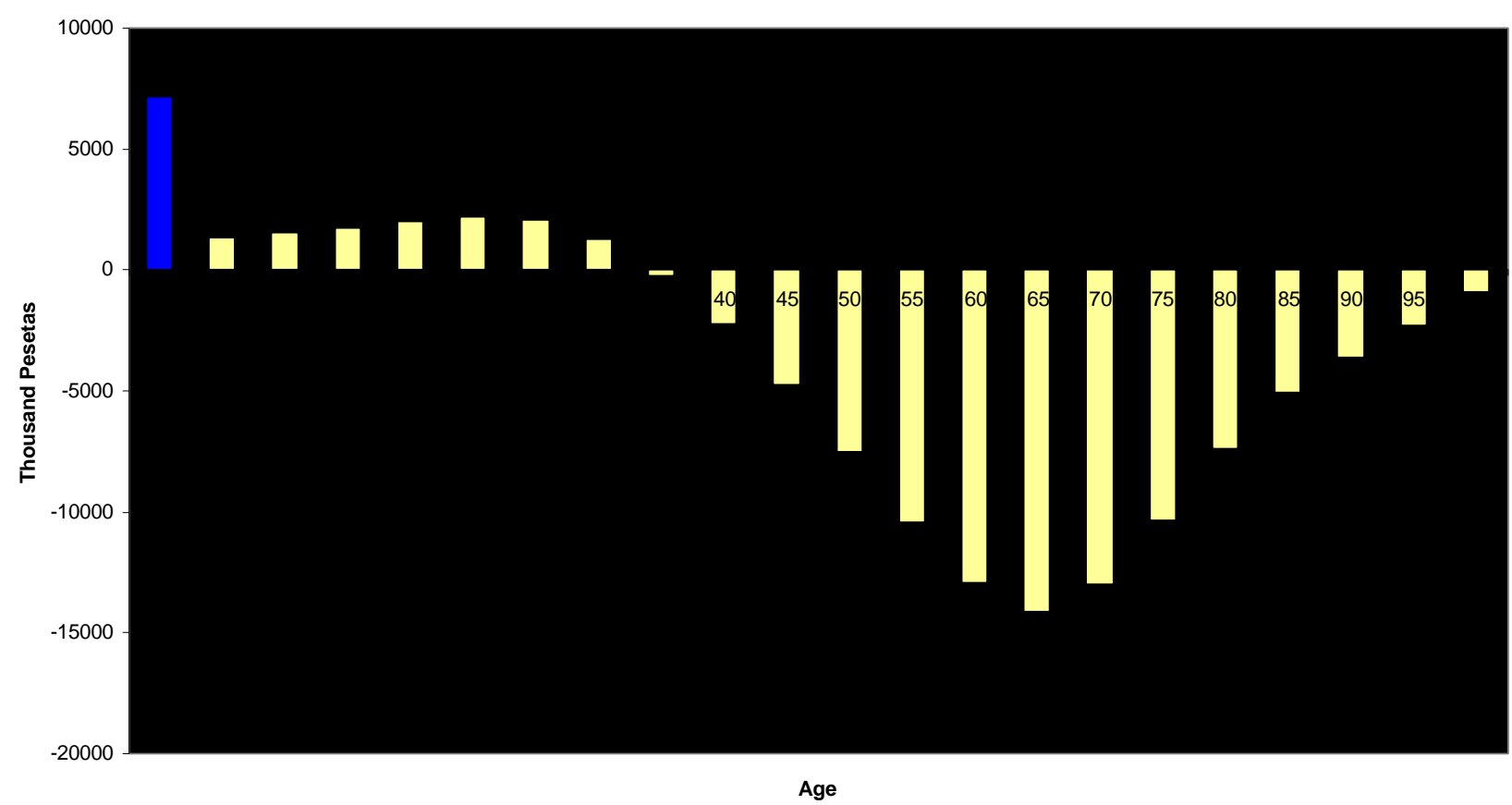

Figure 2: Relative Pension and Contribution Change in a Paygo Setting

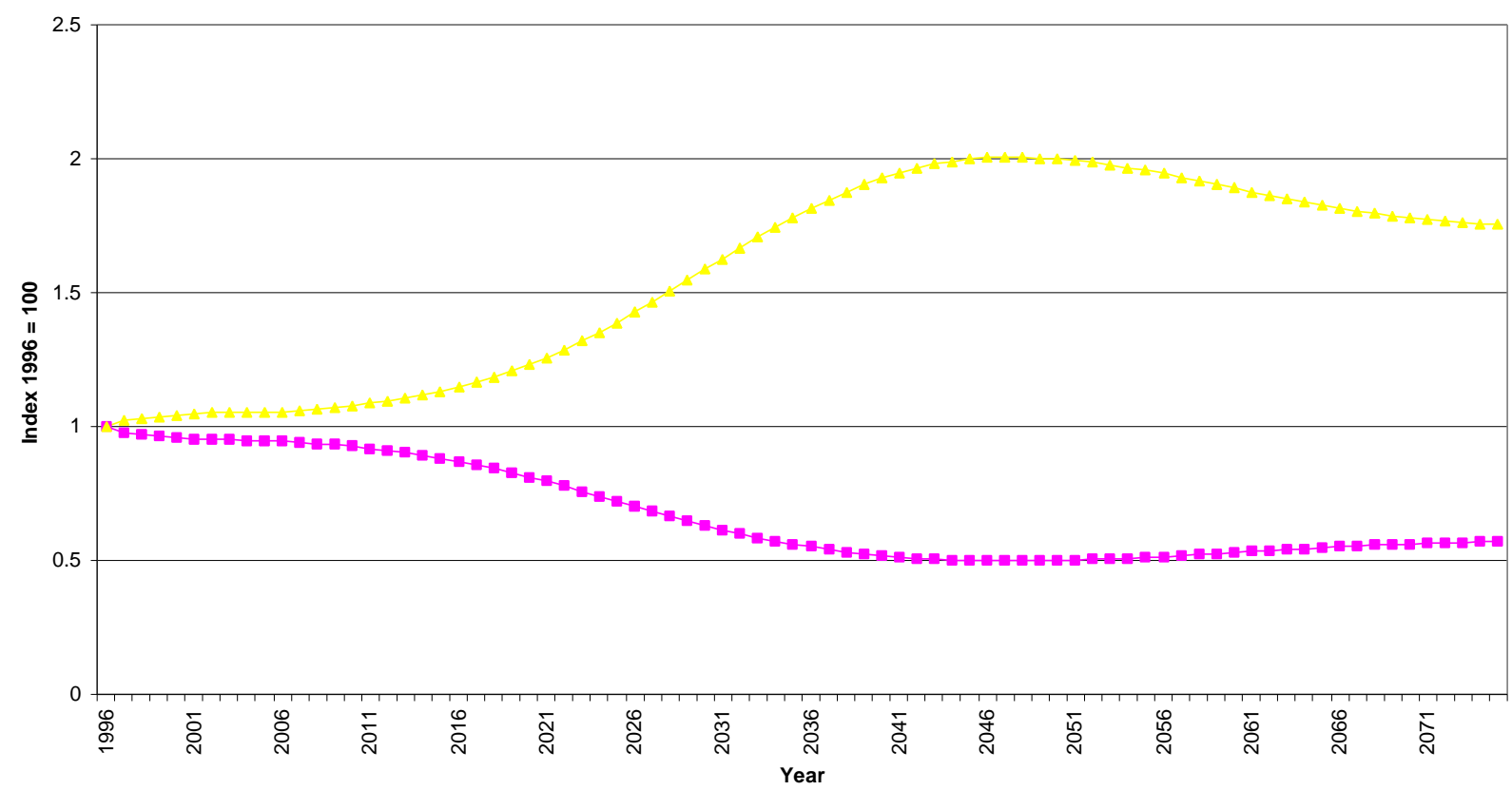


Figure 3: Strategies with Zero Implicit Liabilities - Deviations from Baseine Accounts

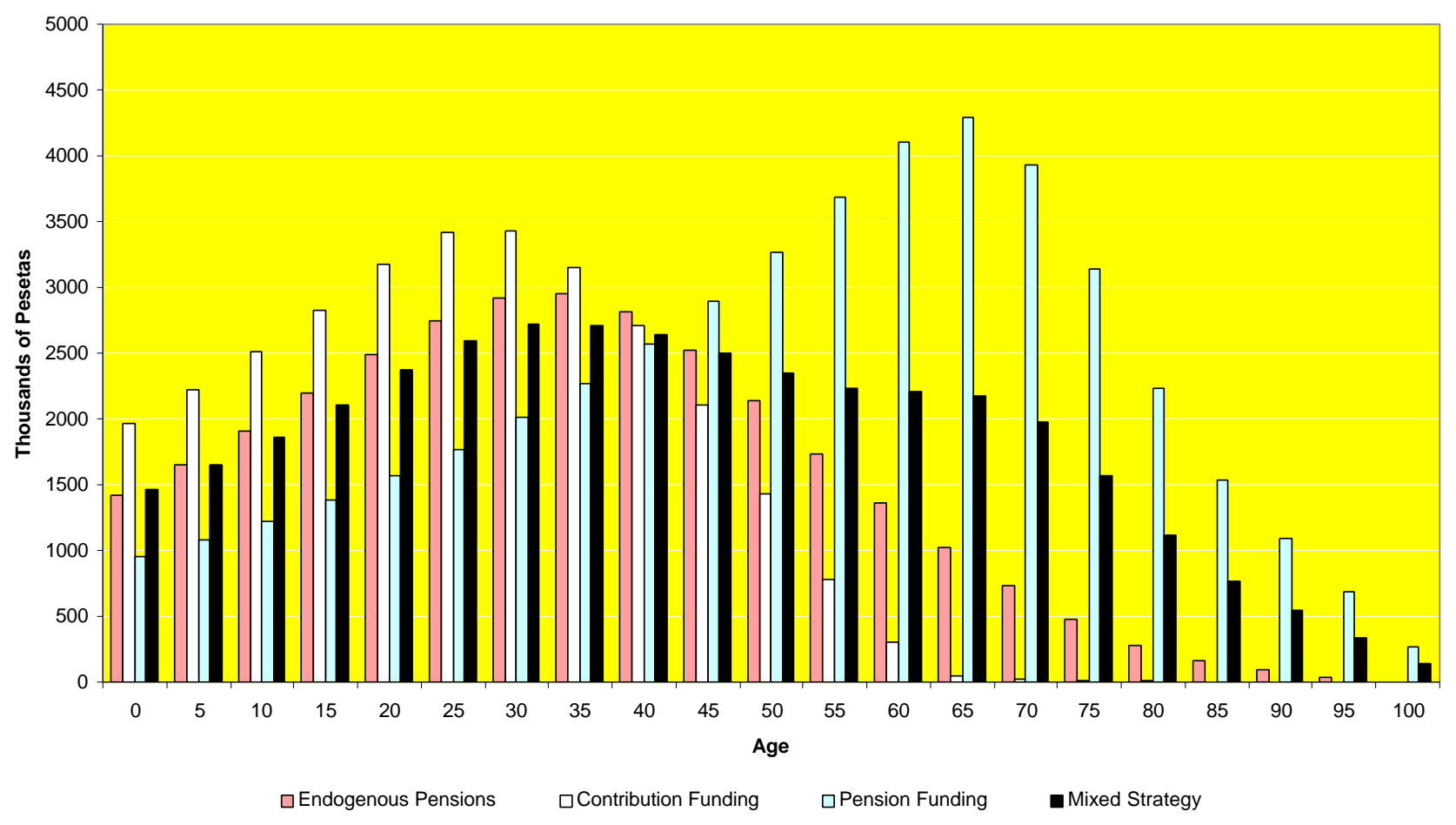




\section{References.}

Abio, G. and C. Patxot (1999) "The cost of raising children: rethinking the welfare effects of a demographic transition on a paygo social security system", mimeo, Universitat de Barcelona.

Alonso, L.M., J. F. Corona and F. Valera (1997) "La armonización fiscal en la Unión Europea", Cedecs Editorial S.L.

Argimón, I. and J.M. González-Páramo (1987) "Traslación e incidencia de las cotizaciones sociales por niveles de renta en España: 1980-84", Documentos de Trabajo de la Fundación FIES, 1.

Auerbach, A.J., J. Gokhale and L.J. Kotlikoff (1991) "Generational accounts: a meaningful alternative to deficit accounting", in D. Bradford (ed.), Tax Policy and the Economy, Vol. 5, Cambridge, MIT Press, pp. 55-110.

Auerbach, A.J., J. Gokhale and L.J. Kotlikoff (1992) “Generational accounting: a new approach to understanding the effects of fiscal policy", Scandinavian Journal of Economics, 9, pp. 303-318.

Berenguer, E., B. Raffelhüschen and H. Bonin (1999) "The Spanish need for a broader tax base", in European Commission (ed.), Generational Accounting in Europe, forthcoming.

Boll, S., B. Raffelhüschen and J. Walliser (1994) "Social security and intergenerational redistribution: a generational accounting perspective", Public Choice, 81, pp. 79-100.

Bonin, H., B. Raffelhüschen and J. Walliser (1997) "Can immigration alleviate the demographic burden: an assessment with generational accounts", Working Papers in Economics, 7/97, University of Bergen. 
Buiter, W.H. (1997) "Generational accounts, aggregate saving and intergenerational redistribution", Economica, 64, pp. 605-626.

Diamond (1994) "Generational accounts and generational balance: an assessment", National Tax Journal, 4, pp. 597-607.

Escobedo, I. (1991) "Un análisis empírico de los efectos finales producidos sobre el empleo industrial por el sistema de financiación de la seguridad social: 1975-1983”, Investigaciones Económicas, 15, pp.169-192.

FBBV (1997) "Pensiones y prestaciones por desempleo", 2ª Edición. Fundación BBV.

Fernández-Cordón, J.A. (1996) “Demografía, actividad y dependencia en España", Serie Economía Pública, Fundación BBV.

Fernández-Cordón, J.A. (1998) "Proyección de la población española 19912026. Revisión 1997”, Documento de Trabajo de FEDEA 98-11.

Gil, J. and G. López-Casasnovas (1998) "Life-time redistribution effects of the Spanish public pension system", Economics Working Paper 242, Universitat Pompeu Fabra.

Gómez-Sala (1993) “Actividad laboral y protección pública a la vejez: un análisis internacional”, Hacienda Pública Española, 126, pp. 51-84.

Haveman, R. (1994) "Should generational accounts replace public budgets and deficits?", Journal of Economic Perspectives, 8, pp. 95-111.

Herce, J.A. and J. Alonso (1998) "Los efectos económicos de la Ley de Consolidación de la Seguridad Social: perspectivas financieras del sistema de pensiones tras su èntrada en vigor", Documento de Trabajo de FEDEA 98-16. IGAE (1997) "Cuentas de las aministraciones públicas 1996”, Intervención General de la Administración del Estado. Ministerio de Economía y Hacienda. 
INSS (1995) "Memoria 1995", Secretaría de Estado de la Seguridad Social, Ministerio de Trabajo y Asuntos Sociales.

Instituto de Demografía (1994) "Poyección de la población española: España 1991-2026. Comunidades Autónomas y Provincias 1991-2006". Madrid.

López-García, M.A. (1996) "Consumption and income as tax bases for social security", Public Finance, 1, pp. 54-70.

MEC (1995) "Memoria de la administración tributaria 1995", Ministerio de Economía y Hacienda.

Monasterio, C., I. Sánchez and F. Blanco (1996) "Equidad y estabilidad del sistema español de pensiones”, Serie Economía Pública, Fundación BBV.

MTSS (1995) "La seguridad social en el umbral del siglo XXI: estudio económico actuarial", Ministerio de Trabajo y Seguridad Social.

MTAS (1997) "Anuario de estadísticas laborales y asuntos sociales", Ministerio de Trabajo y Asuntos Sociales.

MTAS (1999) "Informe económico financiero a los presupuestos de la seguridad social", Ministerio de Trabajo y Asuntos Sociales.

Nadal, M. (1994) "Una nota sobre la sustitución de cotizaciones sociales por IVA", Cuadernos de Actualidad 4/1994, Instituto de Estudios Fiscales.

Patxot, C. (1994) "Efectos del envejecimiento de la población sobre el ahorro", Tesis Doctoral, Departamento de Teoría Económica, Facultad de Ciencias Económicas y Empresariales, Universidad de Barcelona.

Piñera, M. (1996) "Una propuesta de reforma del sistema de pensiones en España", Círculo de Empresarios.

Raffelhüschen, B. (1993) "Funding social security through Pareto-optimal conversion policies", Journal of Economics, Supplement 7, pp. 105 - 131. 
Raffelhüschen, B. and A. Risa (1997) "Generational accounting and intergenerational welfare", Public Choice, 93, pp. 149-163.

Raffelhüschen, B. (1999) "Generational accounting: method, data and limitations", in: European Commission (ed.), Generational Accounting in Europe, forthcoming.

Vilches, G. and R. Salas (1994) "La sustitución de cuotas a la seguridad social a cargo del empresario por IVA", Instituto de Estudios Fiscales.

World Bank (1994) "Averting the old-age crisis: policies to protect the old and promote growth", Washington D. C. 